\title{
Pelindungan Kesehatan Masyarakat terhadap Peredaran Obat dan Makanan Daring
}

\author{
Public Health Protection \\ Against Online Drugs and Food Circulation
}

\author{
Rahmi Yuningsih \\ rahmi.yuningsih@dpr.go.id \\ Pusat Penelitian, Badan Keahlian DPR RI \\ Jl. Jenderal Gatot Subroto, Senayan, Jakarta, 10270
}

Naskah diterima: 28 Januari 2021 | Naskah direvisi: 19 Mei 2021 | Naskah diterbitkan: 30 Juni 2021

\begin{abstract}
Information and communication technology has had an impact on the food and drug online market. However, not all food and drugs in the online market have permits and other requirements that can threaten public health. Against something that is detrimental to society and requires protection from the government, it requires public policy to overcome. In the implementation, public policy requires the role of the bureaucracy, the private sector, and community groups. This paper examines efforts to protect public health against online markets of food and drug from the perspective of the roles of the government, the private sector, and the community. The research approach used is qualitative with a descriptive analysis method. The data collection technique was carried out by means of a literature study. The government has limited resources in monitoring online markets that do not recognize geographic boundaries. The private sector has a role in creating integrated programs that support policies and pay attention to consumer rights. The community also plays a role in increasing awareness and reporting to the marketplace and BPOM on illegal products. Several suggestions, among others, need to increase the socialization of regulations; making technical regulations and pharmaceutical service standards in the online market of drugs; improvement of communication, information, and education; increasing The National of Drug and Food Control resources and increasing the role of the marketplace in filtering every product sold. In addition, it will accelerate the discussion of the drug and food control draft which is included in the Prolegnas 2021.
\end{abstract}

Keywords: food and drug control; illegal drug; online market

Abstrak: Kemajuan teknologi informasi dan komunikasi telah berdampak pada meningkatnya kegiatan jual beli obat dan makanan daring di tengah masyarakat. Pandemi Covid-19 mengubah cara masyarakat mendapatkan obat dari cara konvensional menjadi daring. Namun, tidak semua obat dan makanan yang diedarkan daring memiliki izin edar dan memenuhi persyaratan lainnya sesuai dengan peraturan perundang-undangan sehingga dapat mengancam kesehatan masyarakat. Sementara itu, kebijakan pengawasan terhadap obat dan makanan yang diedarkan daring tersebar dalam berbagai peraturan perundangan. Dalam implementasinya, suatu kebijakan publik memerlukan peran dari pihak birokrasi (pemerintah), pihak swasta, dan kelompok masyarakat. Tulisan ini mengkaji upaya pelindungan kesehatan masyarakat terhadap peredaran obat dan makanan daring dari perspektif peran pemerintah, pihak 
swasta, dan masyarakat. Pendekatan penelitian yang digunakan adalah kualitatif dengan metode deskriptif analisis. Teknik pengumpulan data dilakukan secara studi kepustakaan. Pemerintah memiliki sumber daya terbatas dalam mengawasi peredaran obat dan makanan daring yang tidak mengenal batas geografi. Pihak swasta berperan dalam membuat program terintegrasi yang mendukung kebijakan dan memperhatikan hak-hak konsumen. Masyarakat juga berperan dalam meningkatkan kewaspadaan dan melaporkan kepada pihak lokapasar maupun Badan Pengawas Obat dan Makanan (BPOM) terhadap produk ilegal. Saran perbaikan kebijakan, antara lain: perlu peningkatan sosialisasi peraturan; pembuatan peraturan teknis dan standar pelayanan kefarmasian dalam peredaran daring obat; peningkatan komunikasi, informasi, dan edukasi; peningkatan sumber daya BPOM; dan peningkatan peran lokapasar dalam menyaring setiap produk yang dijual. Selain itu, mempercepat pembahasan RUU tentang Pengawasan Obat dan Makanan (RUU POM) yang masuk Prolegnas Prioritas 2021. RUU POM diharapkan menjadi payung hukum dalam pengawasan obat dan makanan termasuk peredaran daring.

Kata Kunci: obat ilegal; pengawasan obat dan makanan; peredaran daring

\section{Pendahuluan}

Pada era globalisasi saat ini, perkembangan teknologi informasi dan komunikasi telah membuat masyarakat tidak dapat lepas dari penggunaan perangkat komunikasi dan internet. Perkembangan penggunaan media internet sebagai sarana komunikasi menjadi semakin pesat setelah internet mulai dapat diakses melalui telepon seluler dan bahkan kemudian muncul istilah telepon cerdas (smartphone). Dengan hadirnya telepon cerdas, fasilitas yang disediakan dalam berkomunikasi pun semakin beraneka macam, mulai dari layanan pesan singkat atau Short Message Service (SMS), Multimedia Messaging Service (MMS), chatting, e-mail, browsing, serta fasilitas media sosial (Setiadi, 2016). Bahkan internet dengan fasilitas media sosial telah menjadi alat komunikasi utama yang digunakan masyarakat dalam kehidupan sehari-hari.

Sebagai situs jejaring, media sosial memiliki peran penting dalam kegiatan pemasaran suatu produk. Hal ini disebabkan media sosial dapat memainkan peran sebagai media komunikasi di tengah masyarakat. Keunggulan layanan media sosial adalah memberikan ruang komunikasi dua arah antara konsumen-perusahaan dan konsumen-konsumen. Komunikasi dua arah ini memampukan konsumen untuk berpartisipasi, kolaborasi, dan berinteraksi, yang pada intinya konsumen tidak lagi objek tetapi subjek pemasaran (Setiadi, 2016).

Penggunaan media dalam jaringan (daring) saat ini menjadi efektif dalam menjangkau masyarakat dengan akses yang lebih cepat, kapan pun, di mana pun, dan oleh siapa pun. Keefektifan ini sangat memudahkan masyarakat seiring dengan tingkat mobilitas masyarakat yang tinggi yang membutuhkan segala sesuatu dengan segera. Di lain pihak, para pelaku bisnis memerlukan media pemasaran yang efektif dengan tujuan memperluas pangsa pasarnya (Puspitarini \& Nuraeni, 2019: 72).

Bagi pelaku usaha, keberadaan media sosial merupakan media pemasaran yang paling mudah dan murah. Oleh karena itu, wajar media sosial dijadikan sebagai media promosi andalan dengan didukung oleh situs web (website) atau blog perusahaan yang dapat menampilkan profil perusahaan secara lengkap. Bahkan tidak jarang para pelaku usaha hanya memiliki media sosial saja tanpa ada situs web atau pun blog, namun tetap aktif dalam persaingan bisnis.

Media sosial sejatinya memang sebagai media sosialisasi dan interaksi, serta menarik orang lain untuk melihat dan mengunjungi tautan yang berisi informasi mengenai produk dan lain-lain (Setiadi, 2016). Media sosial sama-sama dige- 
mari, baik oleh pelaku usaha maupun konsumen. Masyarakat cenderung mencari informasi dan berkomunikasi melalui media sosial dengan pelaku usaha karena adanya kemudahan, kecepatan, dan ketepatan yang ditawarkan internet. Begitupun dengan pelaku usaha yang memanfaatkan kecenderungan ini sebagai media berpromosi dan berkomunikasi dengan konsumen.

Berdasarkan data Hootsuite yang dikutip dari Laporan Tahunan Kementerian Komunikasi dan Informatika (Kementerian Kominfo) Tahun 2019 menyebutkan bahwa jumlah mobile subscription di Indonesia mencapai 355,5 juta dengan jumlah pengguna internet sebanyak 150 juta. Pengguna media sosial mobile di Indonesia mencapai 130 juta. YouTube (88\%) berada di posisi pertama untuk social network yang digunakan oleh pengguna internet di Indonesia. Posisi kedua dan ketiga untuk social network ditempati oleh Facebook (81\%) dan Instagram (80\%). Sementara itu, untuk aplikasi messenger ditempati oleh WhatsApp (83\%), Line (59\%), dan Facebook Messenger (47\%) (Kementerian Kominfo, 2020). Data Hootsuite pada Februari 2021 yang dikutip dari Kompas tanggal 29 Maret 2021 menunjukkan penggunaan YouTube masih mendominasi di tengah masyarakat, yaitu sebesar 93,8\%, WhatsApp 87,7\%, Instagram 86,6\%, Facebook 85,5\%, Twitter 63,3\%, Line 55,7\%, TikTok 38,7\%, dan Telegram (28,5\%) (Budianto, 2021).

Masyarakat memiliki kecenderungan menggunakan media sosial untuk melakukan komunikasi serta mendapatkan informasi yang dibutuhkan. Namun, tidak dapat dipungkiri bahwa terdapat tujuan lain dalam penggunaan media sosial tersebut. Selain tujuan sosial, penggunaan media sosial juga bisa digunakan untuk tujuan ekonomi di mana masyarakat menggunakan media sosial untuk mempromosikan dan melakukan kegiatan jual beli, termasuk jual beli obat dan makanan. Sering kali ditemui pelaku usaha menjual produk obat dan makanan melalui media Facebook, Instagram, WhatsApp, dan lainnya.

Selain media sosial, dengan maraknya platform e-commerce di dunia digital, memengaruhi gaya hidup masyarakat yang mulai beralih dari gaya belanja yang langsung mendatangi toko-toko perbelanjaan atau gaya konvensional menjadi gaya belanja secara daring melalui lokapasar (marketplace). Menurut Similiarweb yang dikutip dalam Laporan Tahunan Kementerian Kominfo 2019, lokapasar yang sering dikunjungi oleh masyarakat Indonesia antara lain: Shopee, Tokopedia, Bukalapak, OLX, dan Lazada (Kementerian Kominfo, 2020).

Menurut Asosiasi E-Commerce Indonesia (iDea), pada tahun 2012 terdapat sembilan platform e-commerce yaitu: Blibli. com, Tokopedia, OLX, Grazera, Bhinneka. com, Berniaga.com, Multiply, Blanja.com, dan Kaskus. Namun, hingga tahun 2020, terdapat 230 anggota e-commerce di Indonesia (RDPU Komisi IX, 2020). Hampir semua produk yang dicari konsumen tersedia di berbagai platform e-commerce mulai dari kebutuhan sehari-hari hingga investasi emas. Tidak jarang satu akun penjual memiliki banyak akun penjualan di berbagai platform tersebut dengan nama akun yang berbeda-beda. Akun penjual juga berasal dari berbagai skala industri termasuk Usaha Mikro Kecil dan Menengah (UMKM) dan perseorangan.

Dengan adanya program Kementerian Kominfo menggerakkan UMKM Go Online telah menjadikan ekonomi digital bagian dari masa depan Indonesia. Indonesia diprediksi memiliki potensi nilai ekonomi digital yang tinggi. Potensi tersebut harus dimanfaatkan dengan menumbuhkembangkan kewirausahaan digital. Dengan jumlah sekitar 60 juta, UMKM jadi salah satu tulang punggung negara untuk meningkatkan perekonomian nasional.

Teknologi digital sudah masuk ke segala aspek kehidupan masyarakat, mulai dari aspek pembelian produk sehari-hari, 
transportasi, transaksi perbankan, jasa pengiriman, pembayaran tagihan, dan lainnya. Keterlibatan UMKM terhadap platform pasar daring di Indonesia masih sangat rendah di mana diperkirakan hanya $7,7 \%$ yang telah bergabung pada platform pemasaran berbasis daring. Hal ini berdampak pada kecilnya penjualan UMKM pada platform pasar daring yaitu hanya sekitar 5\% dari total produk yang terjual dari UMKM (Kementerian Kominfo, 2020).

Pemerintah menyadari adanya transisi menuju ekonomi digital dan menyambut era digital ini dengan mengembangkan sektor UMKM. Selain mendorong sektor UMKM, tentunya berbagai peredaran daring produk membutuhkan peran pemerintah yang lebih luas sebagai regulator dan pengawas agar masyarakat terlindungi.

Selain itu, pandemi Covid-19 telah membuat pemerintah menerapkan kebijakan Pembatasan Sosial Berskala Besar (PSBB) di mana semua kegiatan dilakukan dari rumah, baik kegiatan belajar, pekerjaan, bahkan peribadatan. Hal ini membuat penggunaan internet menjadi semakin meningkat. Masyarakat menjadi malas untuk beraktivitas di luar rumah termasuk enggan mendatangi fasilitas pelayanan kesehatan untuk memeriksakan kondisi kesehatannya karena adanya kekhawatiran tertularnya Covid-19.

Untungnya masyarakat dipermudah dengan adanya aplikasi jasa konsultasi medis daring melalui telepon seluler masing-masing, misalnya: layanan Halodoc, Alodokter, Grab Health, dan lainnya. Tidak hanya konsultasi dengan tenaga medis, pasien pun dapat memperoleh resep dokter dan surat rujukan ke fasilitas pelayanan kesehatan tingkat lanjut. Kemudahan ini dapat menguntungkan pasien dan masyarakat, seperti semakin aman dalam berkonsultasi medis, waktu yang fleksibel, tidak perlu antri, penawaran yang kompetitif, kecepatan, kemudahan akses kapan pun dan di mana pun, serta memungkinkan kerahasiaan pasien.
Menurut data Asosiasi Telemedisin Indonesia (Atensi) dalam RDPU Komisi IX tanggal 24 September 2020, ada sekitar 29 penyelenggara pelayanan kesehatan elektronik yang telah melibatkan 60 ribu dokter yang melayani 5 juta orang untuk mendapatkan informasi kesehatan. Banyaknya keterlibatan tenaga medis dalam sistem pelayanan kesehatan secara daring merupakan sumber daya yang tidak ternilai dalam mendukung peningkatan derajat kesehatan masyarakat.

Pada skala global, meningkatnya jumlah e-commerce, ditambah dengan meningkatnya penawaran kesehatan secara digital, pelayanan kesehatan langsung kepada pasien, globalisasi produksi, dan distribusi kefarmasian, telah berdampak pada peningkatan apotek daring secara global sebanyak 35.000 (Mackey \& Nayyar, 2016: 116). Pelaku industri farmasi termasuk produsen, distributor, serta fasilitas kefarmasian di rumah sakit dan apotek, mungkin saja selain menjual produk secara konvensional juga melayani produknya secara daring melalui situs web atau akun media sosial mereka. Hal ini menjadi legal ketika mengikuti persyaratan sebagaimana persyaratan, perizinan, dan ketentuan lain dalam peraturan perundang-undangan, baik untuk perizinan fasilitas pelayanan kefarmasian maupun izin edar produk yang ditawarkan.

Daring hanyalah sebuah alternatif dalam kegiatan promosi dan penjualan yang ditawarkan secara konvensional. Namun, hal ini menjadi ilegal apabila institusi atau pelaku penjualan daring tidak memiliki izin usaha, tidak memenuhi persyaratan sertifikasi, lisensi, registrasi, dan persyaratan lain sesuai dengan peraturan perundang-undangan. Produk yang ditawarkan pun tidak memenuhi ketentuan izin edar, persyaratan keamanan, khasiat/manfaat dan mutu, produk ilegal, palsu, kedaluwarsa, terlarang, dan lainnya.

Menurut Qona'ah dan Afianto (2020: 46), obat ilegal adalah obat dengan izin edar 
palsu dan tidak memiliki nomor registrasi; obat yang kandungannya tidak sesuai dengan tulisan yang tercantum dalam kemasan; obat yang standarnya tidak sesuai klaim; obat palsu; penyalahgunaan obat; obat yang telah kedaluwarsa dan dijual kembali; obat impor yang masuk secara ilegal karena tidak berkoordinasi dengan pihak BPOM dan tidak berlabel bahasa Indonesia; dan obat tradisional yang mengandung bahan obat kimia. Berdasarkan kutipan tersebut, obat ilegal yang beredar secara daring sudah diidentifikasikan berbagai jenisnya.

Namun, di luar unsur kesengajaan dan pengenaan sanksi hukum, masih banyak masyarakat yang belum mengerti berbagai obat ilegal yang beredar secara daring. Mereka menjadi konsumen obat ilegal karena sudah terbiasa menggunakan atau pun terpengaruh dari iklan, promosi, dan testimoni pengguna lainnya. Masyarakat juga sering kali tidak menyadari bahwa data transaksi akan terekam dan akan menjadi bukti yang kuat dalam pengawasan yang dilakukan pemerintah.

Pada tahun 2020, BPOM telah merilis hasil pencapaian dan temuan pelanggaran selama tahun 2019. Pelanggaran yang paling sering ditemukan adalah peredaran obat dan makanan yang secara masif masih meluas melalui daring. Obat dan makanan yang diperjualbelikan secara daring banyak yang belum mendapat izin edar BPOM sehingga belum teruji keamanannya.

Ada peluang untuk memalsukan obat keras dengan menambahkan bahan kimia berbahaya, misalnya obat peningkat stamina pria. Konsumen bisa jadi tidak merasakan dampak buruknya secara langsung, hanya merasakan kuat, namun dampak buruknya ke badan akan dirasakan dalam waktu dekat maupun dalam jangka panjang.

Jenis obat lainnya yang biasa diperjualbelikan secara daring dan ilegal adalah misoprostol yang kerap disalahgunakan sebagai obat aborsi ilegal. Obat tersebut tersedia secara bebas pada situs jual beli daring. Obat tersebut termasuk dalam obat yang membutuhkan resep dokter untuk mendapatkannya (Sulaiman, 2019).

Sejatinya obat keras tanpa resep dokter berisiko merugikan pasien karena tidak ada pengawasan dari dokter dan apoteker dalam penggunaan dan penyimpanan obat tersebut. Kondisi pasien dan masyarakat yang lemah di bidang kesehatan menjadikan pasien dan masyarakat tidak dapat mengambil keputusan sendiri dalam penggunaan obat keras. Kemungkinan terjadinya penyalahgunaan, over dosis, kontraindikasi, dan timbulnya efek samping obat pada tubuh dapat merugikan masyarakat dan memperburuk kondisi kesehatan.

Peredaran daring obat dan makanan memiliki risiko beredarnya obat-obatan tertentu yang sering disalahgunakan dan produk ilegal yang merugikan kesehatan masyarakat. Di sisi lain, kebijakan pengawasan peredaran obat dan makanan secara daring masih tersebar dalam berbagai peraturan perundangan. Salah satunya yang dikeluarkan oleh BPOM melalui Peraturan BPOM Nomor 8 Tahun 2020 tentang Pengawasan Obat dan Makanan yang Diedarkan secara Daring.

Dalam teori kebijakan publik, terdapat berbagai aktor yang terlibat dalam implementasi kebijakan publik, yaitu: kalangan birokrasi, pihak swasta, dan peran serta masyarakat. Berdasarkan uraian latar belakang di atas, maka tulisan ini bertujuan mengkaji peran pemerintah, keterlibatan pihak swasta, dan peran serta masyarakat dalam pengawasan peredaran daring obat dan makanan sebagai wujud pelindungan kesehatan masyarakat.

Adapun metode yang digunakan dalam penulisan artikel ini adalah pendekatan kualitatif dengan metode deskriptif analisis. Teknik pengumpulan data dilakukan secara studi kepustakaan. Data dan informasi dikumpulkan dari berbagai literatur terkait seperti buku, jurnal, peraturan perundang-undangan terkait, dokumen 
pemerintah, berita di media massa baik cetak maupun elektronik, dan lainnya. Data dan informasi digabungkan dan dianalisis berdasarkan kelompok-kelompok pembahasan. Tahap terakhir, hasil analisis yang telah dibuat, ditarik kesimpulan sebagai jawaban dari pertanyaan penelitian dan juga beberapa saran atau rekomendasi kepada stakeholder terkait.

\section{Pelindungan Kesehatan Masyarakat}

Undang-undang Nomor 36 Tahun 2009 tentang Kesehatan (UU Kesehatan) mendefinisikan kesehatan sebagai keadaan sehat, baik secara fisik, mental, spiritual, maupun sosial yang memungkinkan setiap orang untuk hidup produktif secara sosial dan ekonomi. Masyarakat yang sehat menjadi investasi yang tidak ternilai dalam pembangunan nasional dan berpengaruh terhadap kesejahteraan suatu bangsa di masa mendatang.

Dalam mewujudkan keadaan sehat, obat dan makanan memegang peranan yang sangat penting. Makanan sangat dibutuhkan sebagai sumber energi seharihari, pendukung pertumbuhan dan perkembangan tubuh, pemeliharaan dan perbaikan sel tubuh, serta penjaga keseimbangan cairan tubuh dan pelindungan tubuh dari penyakit. Tidak kalah penting dari makanan, obat merupakan komoditas kesehatan yang menurut UU Kesehatan adalah bahan atau paduan bahan, termasuk produk biologi yang digunakan untuk memengaruhi atau menyelidiki sistem fisiologi atau keadaan patologi dalam rangka penetapan diagnosis, pencegahan, penyembuhan, pemulihan, peningkatan kesehatan, dan kontrasepsi. Ruang lingkup istilah obat dan makanan dalam konteks pengawasan obat dan makanan yang dilakukan BPOM meliputi obat, bahan obat, narkotika, psikotropika, prekursor, zat adiktif, obat tradisional, suplemen kesehatan, kosmetik, dan pangan olahan.

Selain memberikan khasiat dan manfaat bagi tubuh manusia, obat dan makanan dapat menjadi bahaya bagi tubuh manakala dikonsumsi tidak sesuai dengan ketentuan persyaratan keamanan, khasiat/ manfaat, dan mutu masing-masing produk. Obat yang beredar secara daring sering kali memiliki risiko kesehatan jika obat tersebut merupakan obat palsu yang dapat menyebabkan alergi yang mengancam konsumen yang tidak melalui rekomendasi apoteker saat menjual obat secara daring (Ariestiana, 2020: 71).

Pada umumnya, obat ilegal yang diedarkan secara daring termasuk golongan obat keras (Sulaiman, 2019). Peredaran obat keras yang ilegal secara daring sangat merugikan masyarakat karena penggunaan obat keras secara sembarangan dapat menimbulkan bahaya bagi diri masyarakat sendiri, sebab obat keras adalah obat yang dalam pembeliannya harus disertai dengan resep dokter (Putra, 2014).

Bahayanya peredaran obat keras dan obat-obatan tertentu secara daring tersebut apabila tidak segera ditanggulangi maka akan berdampak mengancam generasi muda serta pertahanan nasional (Ariestiana, 2020: 71). Pada dasarnya obat adalah zat kimia yang masuk ke dalam tubuh sehingga dosis, cara penggunaan, dan cara penyimpanan memerlukan prinsip kehati-hatian di bawah pengawasan tenaga medis dan tenaga apoteker.

Menurut Hardianto (2018), pada sistem jual beli yang dilakukan secara daring, cukup banyak ditemukan pedagang yang menjual produk obat-obatan, suplemen kesehatan hingga makeup yang tidak memperhatikan kualitas produknya. Dengan hanya mengandalkan dan mempercayai distributor, maka dapat dengan mudahnya menjadi pelaku usaha daring tanpa mempertimbangkan aspek keamanan, khasiat/manfaat, dan mutu produk.

Menurut Zuhaid, Turisno, dan Suharto (2016), para pelaku usaha biasanya membuat iklan yang dipasang di situssitus dan melalui akun-akun media sosial. Iklan ini dibuat dengan melanggar hak-hak konsumen, karena di dalam situs web dan 
akun-akun media sosial yang menjual obat tanpa izin edar, biasanya terdapat hal-hal yang bersifat negatif seperti gambar dari iklan tersebut, testimoni-testimoni palsu yang dicantumkan di dalam iklan, dan juga khasiat dengan tingkat kemanjuran yang tinggi. Padahal dalam membuat suatu iklan, pelaku usaha harus memperhatikan asas-asas umum kode etik periklanan agar tidak melanggar hak-hak konsumen.

Pada dasarnya setiap orang dapat menjual apapun secara daring dan semestinya dapat bertanggung jawab atas produk yang dijual. Persaingan usaha membuat akun penjual menyertakan informasi, iklan, dan testimoni berlebihan. Namun sayangnya, sebelum memutuskan membeli masyarakat sering kali melihat testimoni terlebih dahulu. Testimoni palsu memberikan informasi yang salah dan menyesatkan masyarakat. Peredaran obat dan makanan ilegal secara daring beserta testimoni memiliki risiko merugikan kesehatan masyarakat.

Pelindungan kesehatan masyarakat terhadap peredaran obat dan makanan secara daring merupakan upaya yang harus dilakukan oleh semua pihak termasuk seluruh komponen masyarakat. Tujuannya agar masyarakat terhindar dari penggunaan obat ilegal yang dapat membahayakan tubuh. Selain itu, agar masyarakat terhindar dari dampak buruk penggunaan obat yang tidak sesuai dengan peruntukkannya yang dapat memperburuk kondisi kesehatan.

\section{Aktor Implementasi Kebijakan Publik secara Umum}

Terhadap sesuatu yang merugikan masyarakat dan memerlukan upaya pelindungan dari pemerintah, perlu tindakan dalam bentuk kebijakan publik. Secara teori, kebijakan publik merupakan serangkaian tindakan yang ditetapkan dan dilaksanakan atau tidak dilaksanakan oleh pemerintah yang mempunyai tujuan atau berorientasi pada tujuan tertentu demi kepentingan seluruh masyarakat (Islamy, 2009: 20).

Dalam proses analisis kebijakan publik, analisis melibatkan serangkaian aktivitas intelektual yang dilakukan di dalam proses kegiatan yang pada dasarnya bersifat politis. Aktivitas politis tersebut dijelaskan sebagai proses pembuatan kebijakan dan divisualisasikan sebagai serangkaian tahap yang saling bergantung yang diatur menurut urutan waktu yaitu: penyusunan agenda, formulasi kebijakan, adopsi kebijakan, implementasi kebijakan, dan penilaian kebijakan.

Proses pembuatan kebijakan publik bermula dari penyusunan agenda, formulasi, adopsi, implementasi, dan penilaian kebijakan. Proses tersebut mencerminkan aktivitas yang terus berlangsung yang terjadi sepanjang waktu. Setiap proses berhubungan dengan proses berikutnya dan tahap akhir (penilaian kebijakan) dikaitkan dengan tahap pertama (penyusunan agenda) atau tahap di tengah, dalam lingkaran aktivitas yang tidak linear (Dunn, 2003: 23). Setiap proses kebijakan saling berhubungan dan membentuk suatu siklus yang secara kontinu membuat kebijakan publik semakin kokoh dalam mengatasi permasalahan publik.

Seluruh proses pembuatan kebijakan dapat dikatakan penting, namun implementasi kebijakan merupakan tahap yang paling krusial. Suatu program kebijakan harus diimplementasikan agar mempunyai dampak atau tujuan yang diinginkan. Implementasi kebijakan dipandang dalam pengertian yang luas merupakan tahap dari proses kebijakan segera setelah penetapan undang-undang. Implementasi dipandang luas mempunyai makna pelaksanaan undang-undang di mana aktor, organisasi, prosedur, dan teknik bekerja bersamasama untuk menjalankan kebijakan dalam upaya untuk meraih tujuan-tujuan kebijakan atau program (Winarno, 2012: 146).

Dalam tahapan implementasi, terdapat berbagai aktor yang terlibat yang berasal dari kalangan pemerintah maupun 
masyarakat. Aktor tersebut diidentifikasi dari kalangan birokrasi, legislatif, lembaga peradilan, kelompok-kelompok penekan, dan organisasi komunitas (Sagita, Hayu, \& Djumiarti, 2013). Secara umum, dalam implementasi kebijakan peredaran obat dan makanan secara daring terdapat peran dari pihak birokrasi (pemerintah), pihak swasta, dan kelompok masyarakat. Peran tersebut mewakili berbagai kepentingan yang berbeda.

\section{Peran Pemerintah dalam Mengawasi Peredaran Obat dan Makanan secara Daring}

Kebijakan berasal dari kata policy yang pelaksanaannya mencakup peraturanperaturan di dalamnya dan sangat berkaitan dengan proses politik (Islamy, 2009). Peran BPOM dalam mengawasi peredaran obat dan makanan tertera dalam Peraturan Presiden Nomor 80 Tahun 2017 tentang Badan Pengawas Obat dan Makanan. BPOM sebagai regulator dan juga operator mulai dari pengawasan obat dan makanan, baik itu sebelum beredar maupun selama beredar di masyarakat.

Saat ini, belum ada undang-undang yang secara khusus mengatur tentang pengawasan peredaran obat dan makanan secara daring. Namun, peraturan secara umum mengenai peredaran produk tertera dalam berbagai undang-undang seperti dalam Undang-Undang Nomor 19 Tahun 2016 tentang Perubahan Atas UndangUndang Nomor 11 Tahun 2008 tentang Informasi dan Transaksi Elektronik (UU ITE), Undang-Undang Nomor 8 Tahun 1999 tentang Perlindungan Konsumen (UU Perlindungan Konsumen), Undang-Undang Nomor 36 Tahun 2009 tentang Kesehatan (UU Kesehatan), dan Undang-Undang Nomor 18 Tahun 2012 tentang Pangan (UU Pangan).

UU ITE mengatur bahwa pelaku usaha yang menawarkan produk melalui sistem elektronik harus menyediakan informasi yang lengkap dan benar berkaitan dengan syarat kontrak, produsen, dan produk yang ditawarkan. Begitupun dengan UU Perlindungan Konsumen, yang dalam Pasal 4 menyebutkan bahwa konsumen memiliki hak antara lain: hak kenyamanan, keamanan, dan keselamatan dalam mengonsumsi barang dan/atau jasa; dan hak atas informasi yang benar, jelas, dan jujur mengenai kondisi dan jaminan barang dan/atau jasa. Dengan demikian, pelaku usaha memiliki kewajiban memberikan informasi yang benar, jelas, dan jujur mengenai kondisi dan jaminan barang dan/atau jasa. Menjadi hak konsumen dan masyarakat untuk dapat mengakses informasi yang benar, jelas, dan jujur mengenai kandungan produk obat dan makanan. Informasi tersebut juga harus disertakan dalam keterangan produk yang dijual secara daring.

Senada dengan itu, Pasal 98 ayat (2) UU Kesehatan menyebutkan bahwa setiap orang yang tidak memiliki keahlian dan kewenangan dilarang mengadakan, menyimpan, mengolah, mempromosikan, dan mengedarkan obat dan bahan yang berkhasiat obat. Pasal 196 dan Pasal 197 mengatur sanksi pidana pada setiap orang yang dengan sengaja memproduksi atau mengedarkan sediaan farmasi yang tidak memenuhi standar, persyaratan keamanan, khasiat/manfaat atau tanpa izin edar. Pada pasal tersebut, pada peredaran konvensional maupun secara daring, tentunya tidak semua orang bisa menjual obat secara bebas apalagi obat keras yang membutuhkan resep dokter. Hanya apoteker dan tenaga kesehatan yang memiliki wewenang mengedarkan obat.

Selain di bawah pengawasan tenaga medis, apoteker, dan tenaga kesehatan yang berwenang, obat yang digunakan masyarakat semestinya hanya diperoleh dari sarana kefarmasian yang seharusnya digunakan untuk menjual obat yaitu apotek dan toko obat, yang memiliki penanggung jawab apoteker sehingga mengetahui tentang obat-obatan yang akan dijual (Pambudi \& Raharjo, 2020: 22). Dengan 
kata lain, akun penjualan perseorangan tidak dapat menjual obat secara bebas.

Menurut Ariyulinda (2018: 37), pihak yang dapat menjual obat bebas, obat bebas terbatas, obat tradisional, herbal atau suplemen kesehatan melalui media daring hanya apotek dan toko obat berizin yang secara fisik sudah memiliki tempat dan sudah mendapatkan izin sebagai apotek atau toko obat berizin dari pemerintah daerah setempat. Hal ini bertujuan agar pemerintah dapat dengan mudah melakukan pengawasan dalam hal distribusi, transaksi, dan standar serta persyaratan obat yang dijual melalui media daring. Dengan demikian, dapat memberikan jaminan kepada masyarakat bahwa obat yang dijual oleh apotek daring atau toko obat berizin daring merupakan obat-obatan yang telah memiliki izin sehingga dijamin keasliannya.

Kementerian Kesehatan atau dinas kesehatan dalam pembuatan situs bekerja sama dengan Kementerian Kominfo atau dinas komunikasi dan informatika. Melalui situs tersebut apotek dan toko obat berizin dapat mendaftarkan situs mereka. Selain itu, situs tersebut dapat berfungsi memberikan informasi kepada masyarakat mengenai situs apotek daring atau toko obat berizin daring yang terdaftar. Situs apotek daring atau toko obat berizin daring yang sudah diregistrasi akan mempermudah pemerintah menelusuri dan menindak apabila apotek daring atau toko obat berizin daring terbukti melakukan kesalahan.

Begitu pula masyarakat dapat melaporkan pelanggaran yang dilakukan oleh apotek daring atau toko obat berizin daring tersebut jika melakukan pelanggaran kepada Kementerian Kesehatan atau dinas kesehatan. Namun kenyataannya, menurut Mackey dan Nayyar (2016: 116) apotek daring ilegal lebih umum terjadi di ranah digital daripada apotek resmi. Sekitar $96 \%$ dari apotek daring global beroperasi secara ilegal dengan tidak mematuhi peraturan dan persyaratan keselamatan dan melanggar prinsip etika.
Walaupun praktik jual beli obat dan makanan secara daring telah berlangsung sejak lama dan belum ada undangundang yang secara khusus mengatur hal tersebut, namun BPOM baru mengeluarkan peraturannya pada tahun 2020 yaitu melalui Peraturan BPOM Nomor 8 Tahun 2020 tentang Pengawasan Obat dan Makanan yang Diedarkan secara Daring. Pasal 7 menyebutkan bahwa peredaran obat secara daring hanya dapat dilaksanakan untuk obat yang termasuk dalam golongan obat bebas, obat bebas terbatas, dan obat keras. Adapun ketentuan mengenai obat keras dijelaskan pada Pasal 8, yaitu obat keras yang diserahkan kepada pasien secara daring wajib berdasarkan resep yang ditulis secara elektronik sesuai dengan ketentuan peraturan perundangundangan.

Selain ditulis secara elektronik, untuk penyerahan golongan obat keras juga dilaksanakan dengan mengunggah resep ke dalam sistem elektronik. Resep tersebut harus asli dan dapat dipertanggungjawabkan. Adapun teknis penyerahan obat yang diedarkan secara daring dapat dilaksanakan secara langsung kepada pasien atau dikirim kepada pasien secara mandiri oleh apotek atau bekerja sama dengan pihak ketiga yang berbentuk berbadan hukum seperti jasa pengiriman oleh ojek daring. Penyerahan resep asli obat keras dilaksanakan bersamaan dengan penyerahan obat keras oleh apotek atau melalui pihak ketiga kepada pasien. Pasal 11 menyebutkan bahwa seluruh data informasi transaksi elektronik yang terkait dengan kegiatan peredaran obat secara daring wajib diarsipkan dan mampu tertelusur paling singkat dalam batas waktu lima tahun.

Hal penting dalam pengawasan peredaran obat dan makanan secara daring adalah segala hal informasi mengenai apotek dapat diinformasikan dengan jelas dan dapat dilacak sewaktu-waktu seperti informasi perizinan berusaha, apoteker 
penanggung jawab, nomor kontak apotek yang setiap saat dapat dihubungi. Adanya alur penyerahan obat serta pendokumentasian resep elektronik juga perlu diperhatikan. Namun sayangnya, pelayanan kefarmasian secara daring, baik di sarana kefarmasian maupun di sarana pelayanan kesehatan, belum tertera dalam sebuah standar yang dapat menjadi pedoman bagi apoteker untuk terlibat dalam peredaran obat dan makanan secara daring.

Selain itu, Pasal 31 Peraturan BPOM tersebut menyebutkan bahwa peredaran obat dan pangan olahan untuk keperluan medis khusus (PKMK) secara daring dilarang melalui media sosial, daily deals, dan classified Ads. Peraturan ini secara tegas melarang peredaran obat dan makanan PKMK melalui media sosial seperti Facebook, Instagram, Twitter, dan lainnya. Dengan kata lain, peredaran obat dan makanan PKMK melalui media sosial merupakan ilegal. Namun sayangnya, masih banyak masyarakat yang belum mengetahui informasi mengenai substansi ini dan masih melakukan kegiatan jual beli produk tersebut melalui media sosial. Di sisi lain, penggunaan media sosial dengan tujuan promosi dan edukasi produk obat dan makanan PKMK tidak dilarang dalam peraturan tersebut sehingga pelaku usaha dapat memanfaatkan media sosial hanya sebagai media promosi dan edukasi.

Terkait pemanfaatan teknologi telemedisin yang berujung pada penyerahan resep obat secara elektronik dan penebusan obat secara daring, telah terdapat aturan yang mengatur hal tersebut sebagaimana yang tertera pada Surat Edaran Menteri Kesehatan Nomor HK.02.01/Menkes/303/2020 Tahun 2020 tentang Penyelenggaraan Pelayanan Kesehatan Melalui Pemanfaatan Teknologi Informasi dan Komunikasi dalam Rangka Pencegahan Penyebaran Corona Virus Disease 2019 (Covid-19). Penulisan resep elektronik dapat dilakukan secara tertutup melalui aplikasi dokter ke sarana kefarmasian atau secara langsung kepada pasien.
Adapun penulisan resep secara langsung kepada pasien memiliki risiko terjadi kekeliruan. Oleh karenanya, dibutuhkan penekanan bahwa penggunaan resep elektronik hanya sewaktu dan tidak dapat diulang. Resep elektronik harus diberikan pada jasa pengantar obat, baik yang dilakukan oleh apotek daring maupun pihak ketiga jasa pengantaran daring.

Surat edaran tersebut memungkinkan masyarakat dapat memperoleh resep obat dan juga produk obat yang dibutuhkan melalui konsultasi secara virtual tanpa bertatap muka dengan tenaga medis. Semua aktivitas mulai dari pendaftaran, konsultasi, peresepan obat hingga pengantaran obat harus dapat terdokumentasi dan dapat dilacak sewaktu-waktu. Begitupun dengan kerahasiaan pasien, tenaga medis dan aplikasi telemedisin harus menjamin aspek kerahasiaan data kesehatan pasien.

Secara umum, jika dilihat dari sisi pengawasan pemerintah, maka peredaran obat dan makanan di dunia maya semakin sulit untuk dipantau. Hal ini mengingat alamat situs web, akun media sosial, ataupun akun penjualan daring di e-commerce dapat dengan mudah dihapus atau diganti. Menurut Ariestiana (2020: 73) pengawasan menjadi tidak mudah untuk melacak pelaku di media daring karena banyak oknum yang menggunakan akun palsu. Namun demikian, selama tahun 2018 tidak kurang dari 2.217 situs atau akun yang menjual obat tidak sesuai dengan ketentuan dan direkomendasikan untuk diblokir oleh Kominfo. Khusus untuk penjualan obat yang mengandung zat aktif misoprostol secara daring, BPOM telah melaporkan 139 situs yang terdiri dari website, media sosial (Facebook, Instagram, dan Twitter) dan e-commerce (Tokopedia, Shopee, Lazada, dan Bukalapak) ke Kementerian Kominfo. Selain itu, BPOM juga telah merekomendasikan 100 situs yang menjual dan mempromosikan trivam secara bebas kepada Kementerian Kominfo untuk diblokir pada tahun 2018. Trivam meru- 
pakan obat yang disetujui BPOM sebagai anestesi, namun sering disalahgunakan untuk melakukan kejahatan (BPOM, 2019).

Pemerintah memiliki sumber daya yang sangat terbatas dalam mengawasi jutaan akun penjualan yang tersebar di berbagai platform e-commerce dan juga media sosial. Begitupun dengan berbagai macam variasi dari obat dan makanan yang semakin inovatif sesuai kebutuhan pasar. Perangkat pengawasan dalam dunia maya tidak sebanding dengan tingginya minat masyarakat terhadap peredaran obat dan makanan secara daring. Terlebih peredaran secara daring tidak mengenal batas geografi wilayah dan dapat mencakup seluruh dunia.

Sebagai badan yang berwenang melakukan pengawasan obat dan makanan, BPOM memiliki sumber daya yang sangat terbatas dalam mengawasi peredaran obat dan makanan secara daring. Kelembagaan BPOM tidak tersedia di setiap kabupaten/kota, SDM yang mengawasi peredaran daring pun terbatas dan kewenangan yang terbatas dalam menindak dugaan pelanggaran. Oleh karena itu, pengawasan obat dan makanan secara daring tidak hanya bergantung pada peran pemerintah saja khususnya BPOM, tapi juga harus didukung kesadaran para pelaku usaha dan peran serta masyarakat sebagai konsumen.

\section{Peran Pihak Swasta dalam Melakukan Peredaran Obat dan Makanan}

Dalam implementasi kebijakan publik, pihak swasta memiliki peran membuat program-program terintegrasi yang mendukung kebijakan publik (Ulum, Haryono, \& Rozikin, 2013: 156). Namun, sering kali terjadi miskomunikasi antara pembuat kebijakan dengan aktor implementasi kebijakan. Kurangnya frekuensi sosialisasi yang dilakukan oleh pemerintah kepada pihak swasta menjadikan program yang dibuat pihak swasta tidak sejalan dengan kebijakan publik (Ulum, Haryono,
\& Rozikin, 2013: 158). Pemerintah perlu melakukan sosialisasi terhadap berbagai peraturan secara rutin kepada para pihak swasta. Apalagi peraturan BPOM mengenai peredaran obat dan makanan secara daring baru diterbitkan pada tahun 2020 sehingga banyak pihak swasta yang belum mengetahui dan belum melakukan berbagai adaptasi dengan peraturan tersebut.

Dalam melindungi kesehatan masyarakat dari penggunaan obat ilegal yang dijual secara daring, terdapat peran penting dari pihak swasta, yakni peran dari para pelaku usaha daring, platform lokapasar, dan pihak lainnya. Hanya industri farmasi, pedagang besar farmasi, apotek, dan penyelenggara sistem elektronik farmasi (PSEF) yang diperbolehkan menjual obat secara daring, baik kepada sarana kefarmasian, pedagang besar farmasi (PBF) maupun masyarakat.

Industri obat termasuk ke dalam industri yang kompleks karena memerlukan ilmu pengetahuan, riset, teknologi, SDM, regulasi, material bahan baku yang didominasi impor, sarana dan prasarana tertentu, biaya tinggi, dan rantai distribusi yang panjang. Industri obat memiliki nilai komersial dan nilai ekonomi yang tinggi di samping memiliki nilai sosial yang tinggi dalam mencegah, merawat, dan menyembuhkan penyakit. Pelaku usaha di industri obat perlu menempatkan konsumen dan masyarakat sebagai subjek yang perlu dilindungi keamanan dan keselamatannya dalam penggunaan obat dan makanan.

Dalam persaingan bisnis saat ini, penggunaan internet dalam bentuk media sosial mempermudah pelaku usaha mempromosikan produknya dan memberikan edukasi pada masyarakat. Penggunaan internet melalui situs web dan lokapasar juga diperlukan pelaku usaha dalam penjualan produk. Selain memenuhi persyaratan sebagaimana ketentuan dan perizinan dalam penjualan konvensional, ada beberapa hal yang perlu diperhatikan dalam penjualan daring, antara lain: mencantumkan informasi produk obat 
dan makanan yang jelas beserta tanggal produksi, nomor batch, dan tanggal kedaluwarsa; mencantumkan label berbahasa Indonesia; mencantumkan nomor kontak telepon untuk komunikasi pasca pembelian; mencantumkan surat izin usaha apotek/toko obat, surat izin praktik apoteker penanggung jawab, surat izin usaha perdagangan kecil dan lainnya; mencantumkan tanda situs terpercaya; pranala (hyperlink) yang jelas; cara transaksi yang aman; terdaftar dalam situs farmasi daring yang aman; tidak menjual obat keras tanpa resep dokter; dan tidak menjual melalui media sosial.

Sebelum penjual membuka akun, lokapasar wajib memberikan informasi mengenai larangan penjualan produk obat dan makanan yang tidak sesuai dengan ketentuan peraturan, seperti larangan menjual obat keras, narkotika, psikotropika, dan obat-obatan lain yang tidak terdaftar di BPOM maupun dinas kesehatan. Selain itu, individu atau perseorangan dilarang menjual obat secara daring melainkan harus terdaftar melalui perizinan apotek/PSEF. Lokapasar wajib memverifikasi setiap pembukaan akun penjual obat dan makanan. Lokapasar perlu membuat deteksi otomatis untuk mengenali setiap produk obat ilegal yang diunggah, baik yang terpasang pada lokapasar resmi maupun individu, tanpa izin menjual obat. Lokapasar perlu melakukan penghapusan produk, penghentian sementara, bahkan penutupan terhadap akun jika tidak sesuai SOP.

Selain pada produk, lokapasar juga mengawasi setiap testimoni terhadap produk yang dijual, kemudian menyediakan tombol laporan yang terhubung ke layanan pengaduan lokapasar maupun BPOM/tim siber. Lokapasar terus melakukan pemantauan terhadap akun yang menjual obat keras di platformnya. Lokapasar bekerja sama dengan BPOM dan dinas kesehatan dalam memantau promosi dan penjualan produk. Terhadap setiap temuan BPOM, lokapasar wajib menindaklanjuti rekomen- dasi BPOM. Peran asosiasi e-commerce dan juga lokapasar menjadi penting untuk terus mengingatkan anggotanya agar mematuhi ketentuan dan persyaratan dan kooperatif dalam mengawasi peredaran obat ilegal.

\section{Peran Serta Masyarakat dalam Mengakses Peredaran Obat dan Makanan}

Salah satu karakteristik pelayanan kesehatan yang membedakannya dari pelayanan jasa lainnya adalah asymmetry of information, yaitu konsumen pelayanan kesehatan berada pada posisi yang lemah, sedangkan penyelenggara kesehatan seperti tenaga medis dan tenaga kesehatan mengetahui lebih banyak tentang manfaat dan kualitas pelayanan yang ditawarkan. Konsumen pelayanan kesehatan dalam kedudukannya sebagai subjek hukum juga berada pada posisi yang lemah. Namun sebaliknya, pelaku usaha di bidang kesehatan menempati posisi yang kuat sehingga membuat konsumen tidak memiliki opsi tawar (Sugiantari, 2016: 195). Secara sosiologis kedudukan pasien lebih rendah daripada kedudukan tenaga kesehatan (Maisusri, 2016: 2). Hal ini membuat masyarakat mempercayai tenaga kesehatan dalam mendapatkan pelayanan kesehatan yang dibutuhkan. Namun di sisi lain, kemajuan teknologi membuat masyarakat dapat mengakses informasi obat dan makanan secara daring, baik melalui media sosial maupun platform e-commerce.

Masyarakat dalam mengambil keputusan medis pun sering kali dipengaruhi oleh tenaga medis dan tenaga kesehatan. Namun dengan adanya kemudahan internet, masyarakat dapat dengan leluasa mengambil keputusan dengan lebih dahulu mengakses obat dan informasi obat yang dibutuhkan melalui media internet. Sering kali masyarakat tidak memahami bahwa obat yang dibutuhkan termasuk dalam kategori obat keras yang penggunaannya membutuhkan resep dan pengawasan dokter maupun obat lainnya yang sering 
disalahgunakan. Masyarakat menganggap obat tersebut sudah lumrah dijual di pasaran, apalagi dijual daring. Begitupun dengan khasiat dari obat keras tersebut, masyarakat sudah menganggap biasa untuk dikonsumsi tanpa resep dan pengawasan dari dokter. Oleh karena itu, menjadi penting untuk meningkatkan kesadaran dan pengetahuan masyarakat mengenai obat keras dan obat yang sering disalahgunakan.

Walaupun tidak dapat dihindari adanya kemudahan mendapatkan obat secara daring, sebaiknya aspek kehatihatian selalu ditegakkan oleh masyarakat. Masyarakat perlu meningkatkan kewaspadaan terhadap produk obat dan makanan dengan selalu mengecek informasi tanggal produksi, tanggal kedaluwarsa, logo obat, izin edar BPOM atau izin pangan industri rumah tangga dari dinas kesehatan, komponen kandungan, kontraindikasi, dan lainnya.

Tentu meningkatkan kesadaran dan pengetahuan masyarakat bukan sesuatu yang mudah, melainkan membutuhkan waktu, upaya terus-menerus, dan sumber daya lainnya. Media promosi kesehatan dapat digunakan untuk meningkatkan kesadaran dan pengetahuan masyarakat, misalnya melalui iklan layanan publik di televisi nasional, radio, media massa cetak, media sosial, situs web pada waktu strategis dan rutin, menggunakan media spanduk yang dipasang di tiap RT/RW, fasilitas pelayanan kesehatan, sekolah, pasar, dan fasilitas umum lainnya.

Selain meningkatkan kewaspadaan, masyarakat juga turut berperan serta dalam mengawasi peredaran obat dan makanan secara daring. Masyarakat perlu melaporkan kepada pihak lokapasar maupun BPOM mengenai produk obat dan makanan yang tidak memenuhi ketentuan dan persyaratan, penggunaan gambar yang tidak pantas, dan penyertaan testimoni yang berlebihan. Namun sayangnya, masyarakat sering kali kurang berperan aktif dalam memberikan informasi secara akurat pada pihak kepolisian terhadap halhal yang berkaitan dengan peredaran ilegal obat-obatan di media daring yang disebabkan rasa takut dan cenderung bersikap acuh (Ariestiana, 2020: 73).

Pengawasan peredaran daring obat dan makanan juga melibatkan semua elemen masyarakat termasuk para publik figur, pemengaruh (influencer), narablog (blogger) dan lainnya yang menjadi panutan di media sosial. Pemberian komunikasi, informasi, dan edukasi kepada masyarakat dapat meningkatkan pemahaman dan kewaspadaan terhadap penyalahgunaan obat (Qona'ah \& Afianto, 2019: 46).

Sebagai bagian dari masyarakat, organisasi profesi apoteker juga berperan dalam peredaran obat dan makanan secara daring, yaitu dengan menjembatani kebijakan publik kepada para apoteker dan membina apoteker agar kompetensinya sejalan dengan perkembangan peredaran obat dan makanan yang juga dilakukan secara daring. Kompetensi apoteker dalam peredaran obat dan makanan secara daring belum didukung oleh standar pelayanan kefarmasian yang mengatur mekanisme dan sistem peredaran obat secara daring. Kebutuhan akan standar pelayanan yang detail akan menjadi pedoman dalam berpraktik dan dapat menghilangkan keraguan apoteker untuk mendukung peredaran obat dan makanan secara daring yang sesuai dengan ketentuan peraturan.

\section{Penutup}

Kemajuan teknologi informasi dan komunikasi saat ini telah berdampak pada meningkatnya peredaran obat dan makanan secara daring melalui lokapasar, situs web, maupun media sosial. Pandemi Covid-19 yang melanda Indonesia sejak awal Maret 2020 telah berdampak pada meningkatnya konsultasi medis melalui layanan telemedisin yang memudahkan masyarakat dalam mendapatkan resep elektronik dan obat yang dibutuhkan. Sama halnya dengan kegiatan jual 
beli secara konvensional, peredaran obat dan makanan secara daring juga harus memenuhi ketentuan peraturan perundang-undangan.

Namun sayangnya, kemudahan internet sering disalahgunakan dengan menjual obat ilegal yang mengancam kesehatan masyarakat. Praktik jual beli obat dan makanan secara daring telah berlangsung sejak lama, namun belum ada undang-undang yang secara khusus mengatur peredaran obat dan makanan secara daring. BPOM baru mengeluarkan peraturannya pada tahun 2020 yaitu melalui Peraturan BPOM Nomor 8 Tahun 2020 tentang Pengawasan Obat dan Makanan yang Diedarkan secara Daring.

Kebijakan tersebut memerlukan peran para aktor dalam implementasinya, yaitu: pihak birokrasi (pemerintah), pihak swasta, dan kelompok masyarakat. Pemerintah memiliki sumber daya yang sangat terbatas dalam mengawasi jutaan akun penjualan dan berbagai macam variasi obat dan makanan. Perangkat pengawasan dalam dunia maya tidak sebanding dengan tingginya minat masyarakat terhadap peredaran obat dan makanan secara daring. Terlebih peredaran secara daring tidak mengenal batas geografi wilayah dan dapat mencakup seluruh dunia.

Dalam implementasi kebijakan, pihak swasta memiliki peran membuat programprogram terintegrasi yang mendukung kebijakan publik. Masyarakat dapat berperan dalam meningkatkan kewaspadaan dan melaporkan kepada pihak lokapasar maupun BPOM terhadap produk obat dan makanan yang tidak memenuhi ketentuan dan persyaratan, penggunaan gambar yang tidak pantas, dan penyertaan testimoni yang berlebihan.

Beberapa saran kepada pemerintah, antara lain: perlu adanya sosialisasi yang masif terhadap peraturan peredaran obat dan makanan secara daring; dibuatnya peraturan dan standar pelayanan yang lebih teknis dan detail terkait peran apoteker dalam peredaran obat dan makanan secara daring berupa standar pelayanan kefarmasian; meningkatnya komunikasi, informasi, dan edukasi kepada masyarakat awam untuk tidak menjual produk obat secara daring; meningkatnya sumber daya BPOM baik di pusat maupun di setiap kabupaten/kota; dan meningkatnya peran lokapasar dalam memfilter setiap produk yang dijual.

Selain itu, RUU POM yang telah masuk dalam Prolegnas Prioritas 2021 memerlukan percepatan pembahasan dengan pemerintah. RUU POM diharapkan menjadi payung hukum dalam pengawasan obat dan makanan termasuk peredaran obat dan makanan secara daring.

\section{Daftar Pustaka}

Ariestiana, E. (2020). Analisis penanggulangan peredaran obat keras dan obat- obat tertentu melalui media online analysis of drugs and certain medicines circulation through online media. Indonesian Private Law Review, 1(2), 59-68. doi: 10.25041/ iplr.vli2.2054

Ariyulinda, N. (2018). Urgensi pembentukan regulasi penjualan obat melalui media online. Jurnal Legislasi Indonesia, 15(1), 37-48. Diakses dari https://e-jurnal. peraturan.go.id/index.php/jli/article/ download/10/pdf

Asosiasi Telemedisin Indonesia. (2020, September 25). Masukan Atensi terhadap RUU BPOM. RDPU RUU POM Komisi IX $D P R$ RI dengan Atensi, BPKN, BPP, BSN, YLKI, Idea, Atensi, dan AHI, Jakarta. Tidak diterbitkan.

Badan Pengawas Obat dan Makanan. (2019). Penjelasan BPOM RI tentang peredaran obat keras yang dijual online/daring. Diakses dari https://www.pom.go.id/ new/view/more/klarifikasi/97/PenjelasanBpom-Ri-Tentang-Peredaran-Obat-KerasYang-Dijual- online-Daring.html

Budianto, Y. (2021, Maret 29). Pembuatan konten kreatif skala domestik naik daun. Kompas, hal. B. 
Dunn, W. N. (2003). Pengantar analisis kebijakan publik. Yogyakarta: Gadjah Mada University Press.

Hardianto, M. H. (2018). Peranan Balai Besar Pengawas Obat dan Makanan (BBPOM) terhadap peredaran produk obat-obatan dalam rangka perlindungan konsumen di Kota Mataram [Disertasi]. Diakses dari http://eprints.unram.ac.id/id/eprint/10641

Islamy, M. I. (2009). Prinsip-prinsip perumusan kebijaksanaan negara. Jakarta: Bumi Aksara.

Kementerian Komunikasi dan Informatika. (2020). Laporan tahunan kementerian komunikasi dan informatika tahun 2019. Jakarta: Kementerian Komunikasi dan Informatika.

Mackey, T. K., \& Nayyar, G. (2016). Digital danger: A review of the global public health, patient safety and cybersecurity threats posed by illicit online pharmacies. British Medical Bulletin, 118, 115-131. doi: 10.1093/bmb/ldw016

Maisusri, S. (2016). Penegakan hukum terhadap tindak pidana peredaran obat impor yang tidak memiliki izin edar oleh penyidik pegawai negeri sipil balai besar pengawas obat dan makanan di Pekanbaru. Jurnal online Mahasiswa, 3(2), 1-15. Diakses dari https://www.neliti.com/ publications/183139/penegakan-hukumterhadap-tindak-pidana-peredaran-obatimpor-yang-tidak-memiliki

Pambudi, D. B., \& Raharjo, D. (2020). Perlindungan hukum bagi konsumen terhadap obat tradisional tanpa izin edar di media online. The 11th University Research Colloquium 2020 Universitas Aisyiyah Yogyakarta, 21-25.g. Diakses dari http://repository.urecol.org/index.php/ proceeding/article/view/984

Puspitarini, D. S., \& Nuraeni, R. (2019). Pemanfaatan media sosial sebagai media promosi (studi deskriptif pada happy go lucky house). Jurnal Common, 3(1), 7180. Diakses dari https://ojs.unikom.ac.id/ index.php/common/article/view/1950/1307

Putra, D. A. (2014). Pengawasan penjualan obat keras oleh badan pengawas obat dan makanan Pekanbaru berdasarkan undang- undang nomor 36 tahun 2009 tentang kesehatan. Jurnal online Mahasiswa Fakultas Hukum, 1(2). Diakses dari https:// jom.unri.ac.id/index.php/JOMFHUKUM/ article/view/2034/1988

Qona'ah, S., \& Afianto, H. (2020). Strategi BPOM dalam upaya mengatasi pemberantasan dan penyalahgunaan obat ilegal melalui gerakan "waspada obat ilegal". Journal Komunikasi, 11(1), 43-50. doi: 10.31294/jkom

Sagita, R. A., Hayu, I., \& Djumiarti, T. (2013). Analisis peran aktor implementasi dalam kebijakan pengelolaan sampah di Kota Semarang. Journal of Public Policy and Management Review, 2(4), 61-70. doi: 10.14710/jppmr.v2i4.3559

Setiadi, A. (2016). Pemanfaatan media sosial untuk efektifitas komunikasi. Cakrawala Jurnal Humaniora Bina Sarana Informatika, 16(2). doi: 10.31294/jc.v16i2.1283

Sugiantari, A. A. P. W. (2016). Karakteristik pelayanan kesehatan dalam perlindungan pasien. Jurnal Universitas Mahasaraswati Press, 5(2), 185-200. Diakses dari https://jurnal.unmas.ac.id/index.php/ ProsemHukum/article/view/540/502

Sulaiman, M. R. (2019, Desember 19). Penjualan obat keras online jadi pelanggaran terbanyak, ini respons BPOM. Suara.com. Diakses dari https://www. suara.com/health/2019/12/19/144254/ penjualan-obat-keras-online-jadipelanggaran-terbanyak-ini-responsbpom?page $=$ all

Ulum, S., Haryono, B. S., \& Rozikin, M. (2013). Analisis peran multiaktor dalam implementasi kebijakan minapolitan berbasis sustainable development. Jurnal Administrasi Publik (JAP), 1(1), 154-162. Diakses dari http://administrasipublik. studentjournal.ub.ac.id/index.php/jap/ article/view/23/21

Winarno, B. (2012). Kebijakan publik: teori, proses, dan studi kasus. Yogyakarta: CAPS.

Zuhaid, M. A. N., Turisno, B., \& Suharto, R. (2016). Perlindungan konsumen terhadap peredaran obat tanpa izin edar yang dijual secara online di Indonesia. Diponegoro 
Law Journal, 5(3), 1-12. Diakses dari https://ejournal3.undip.ac.id/index.php/dlr/ article/view/12057/11710 